medRxiv preprint doi: https://doi.org/10.1101/2021.03.17.21253801; this version posted March 20, 2021. The copyright holder for this preprint (which was not certified by peer review) is the author/funder, who has granted medRxiv a license to display the preprint in

It is made available under a CC-BY 4.0 International license.

\title{
Impact of the COVID-19 pandemic on surgical procedures in Brazil: a descriptive study
}

Bárbara Okabaiasse Luizeti ${ }^{1}$, Victor Augusto Santos Perli ${ }^{1}$, Gabriel Gonçalves da Costa ${ }^{2,3}$, Igor da Conceição Eckert $^{4}$, Aluisio Marino Roma ${ }^{1,5}$, Karina Miura da Costa ${ }^{1,6}$

${ }^{1}$ Department of Medicine, Universidade Cesumar (Unicesumar), Maringá, PR, Brazil

${ }^{2}$ Department of Nutrition, Universidade Federal do Rio de Janeiro (UFRJ), Rio de Janeiro, RJ, Brazil

3 Instituto de Bioquímica Médica Leopoldo de Meis, Rio de Janeiro, RJ, Brazil

${ }^{4}$ Department of Nutrition, Universidade Federal de Ciências da Saúde de Porto Alegre (UFCSPA), Porto Alegre,

RS, Brazil

${ }^{5}$ Faculdade de Medicina de São José do Rio Preto (FAMERP), São José do Rio Preto, SP, Brazil

${ }^{6}$ Faculdade de Medicina de Ribeirão Preto da Universidade de São Paulo (FMRP-USP), Ribeirão Preto, SP, Brazil

Abstract

Background: The COVID-19 pandemic has deeply affected medical practice, and changes in healthcare activities were needed to minimize the overload and avoid healthcare systems collapse. The aim of this study was to evaluate the impact of the pandemic on surgical procedures in Brazil.

Materials and Methods: We conducted a descriptive study of the number of hospitalizations for surgical procedures in Brazil from 2016 to 2020. Data were collected from the Brazilian Department of Informatics of the Unified Health System (DATASUS). Analyzes were performed according to the type of procedure, geographical region, subgroups of surgical procedures, and the number of surgeries from 2020 were compared with the average from 2016 to 2019.

Results: There were 4,009,116 hospitalizations for surgical procedures in the Brazilian Public Health System in 2020. When comparing it to the average of hospitalizations from $2016-2019$, there was a decrease of $14.88 \%$ [95\%IC (14.82-14.93)]. Decrease rates were 34.82\% [95\%IC (34.73-34.90)] for elective procedures and $1.11 \%$ [95\% IC (1.07-1.13)] for urgent procedures. Decrease rates were similar in all the five regions of the country (average 14.17\%). Surgical procedure subgroups with the highest decrease rates were endocrine gland surgery $(48.03 \%)$, breast surgery $(40.68 \%)$, oral and maxillofacial surgery $(37.03 \%)$, surgery of the upper airways, face, head and neck (36.06\%), and minor surgeries and surgeries of skin, subcutaneous tissue and mucosa (33.16\%). Conclusion: The overload of healthcare facilities has demanded a reduction of non-urgent activities to prevent a collapse of healthcare systems, resulting in a decrease in elective surgeries. Recommendations about the performance of surgical procedures were made, and continuous refinements of these recommendations are encouraged.

Keywords: COVID-19; Elective surgical procedure; Hospitalization; SARS-CoV-2; Surgery.

\section{Introduction}

Coronavirus Disease 2019 (COVID-19) was first reported in late December 2019 in Wuhan, Hubei Province of China [1,2]. The disease spread quickly: by the end of January 2020, it was stated as an NOTE: This preprint reports new research that has not been certified by peer review and should not be used to guide clinical practice. 
medRxiv preprint doi: https://doi.org/10.1101/2021.03.17.21253801; this version posted March 20, 2021. The copyright holder for this preprint (which was not certified by peer review) is the author/funder, who has granted medRxiv a license to display the preprint in

It is made available under a CC-BY 4.0 International license.

international public health emergency, and, in March, the World Health Organization (WHO) declared COVID-19 as a pandemic [3,4].

Since the beginning of the outbreak, there was concern about the impact on healthcare systems. Due to the risk of nosocomial transmission, possible lack of personal protective equipment (PPE), overflow of healthcare facilities, and limited medical resources [5,6], there was a disruption in delivering surgical care to millions of patients [7-9].

The relation between surgery and the outbreak is complex: the risk of exposure and nosocomial infection is higher in the context of a surgical procedure; postoperative care may need hospitalization and intensive care, thus reducing the availability of these supports to COVID-19 patients. Other situations affecting surgical practice were also seen, such as the shortage of medications and blood components $[7,8]$.

In this context, many countries canceled elective procedures to redirect surgical resources and workforce to COVID-19 patients [9-11]. Furthermore, considering that the healthcare professionals could be at high risk of exposure to the virus during surgical procedures [12], specific institutional protocols were developed for operating rooms depending on the type of surgery [13,14].

The aim of this study was to analyze the impact of the COVID-10 pandemic on surgical procedures in Brazil.

\section{Materials and Methods}

This was a descriptive study, based on publicly available data from the Brazilian Department of Informatics of the Unified Health System (DATASUS), which includes only data from the Brazilian public health system, collected in the public health information tab - TABNET.

Data from 2016 to 2020 were collected according to the procedure and Brazil's geographical regions. Brazil is divided into five regions encompassing 27 federative units: North (seven federative units); Northeast (nine federative units); Midwest (four federative units); Southeast (four federative units); and South (three federative units) [15].

Data were also collected according to the type of procedure, which was classified in TABNET as "elective procedure", "urgent procedure", "accident in the workplace or at the duty of a company", "accident on the way to work", "other types of traffic accidents" and "other types of injury or poisoning by chemical or physical agents". The last four were computed in a single group called "other procedures".

Historical time series charts were performed by month and by year for the variables mentioned above. For 2020, hospitalizations for total surgical procedures were listed per month and per region. Analyses were performed by type of surgical procedure and by region, comparing the average of hospitalizations rates from 2016 to 2019 with the hospitalization rates in 2020.

Surgical procedures subgroups were analyzed, comparing the averages of hospitalizations from 2016 to 2019 with hospitalizations in 2020 to determine the subgroups most affected by the COVID-19 pandemic.

Analyses were performed in software R for statistical computing, version 4.0.3 (R Core Team, 
medRxiv preprint doi: https://doi.org/10.1101/2021.03.17.21253801; this version posted March 20, 2021. The copyright holder for this preprint (which was not certified by peer review) is the author/funder, who has granted medRxiv a license to display the preprint in It is made available under a CC-BY 4.0 International license.

Vienna, Austria). This article is compliant with the STROCSS criteria (Strengthening the reporting of cohort studies in surgery).

\section{Results}

The number of hospitalizations for surgical procedures from 2016 to 2020 is shown in Table 1 and Figure 1, with temporal distribution of total, elective and urgent surgical procedures. There was an increase in surgeries from 2016 to 2019, and a reduction in 2020. When comparing the average of hospitalizations from 2016-2019 and the hospitalizations in 2020, there was a $14.88 \%$ reduction [95\% IC (14.82-14.93)] in total surgical procedures (Table 1). Elective procedures showed a greater decrease, with 34.82\% [95\%IC (34.73-34.90)] less elective procedures and 1.11\% [95\%IC (1.07-1.13)] less urgent procedures in 2020.

Figure 1. Temporal evolution of the number of elective, urgent and total surgical procedures in Brazil between 2016 and 2020 .

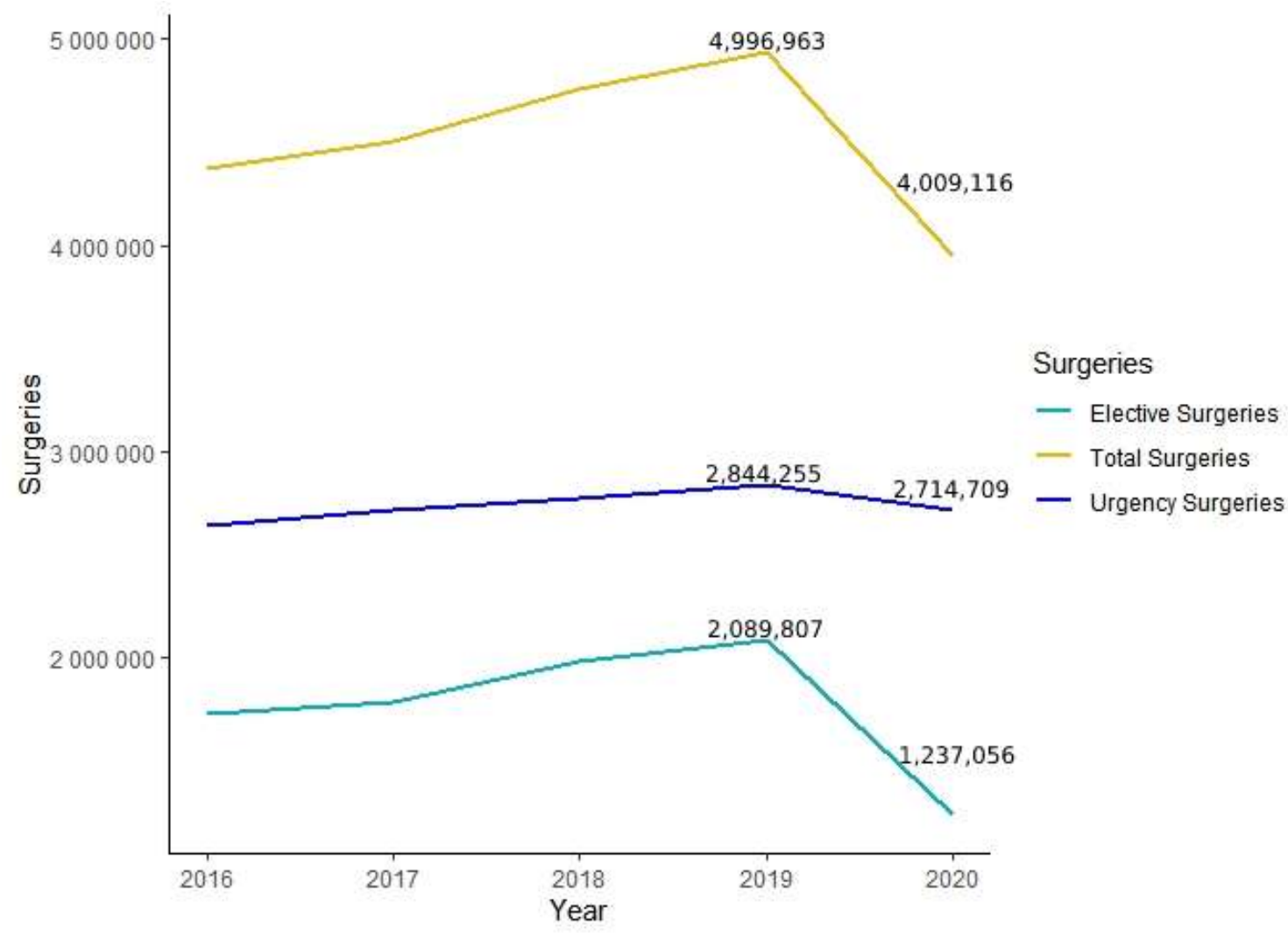


medRxiv preprint doi: https://doi.org/10.1101/2021.03.17.21253801; this version posted March 20, 2021. The copyright holder for this preprint (which was not certified by peer review) is the author/funder, who has granted medRxiv a license to display the preprint in It is made available under a CC-BY 4.0 International license.

Table 1. Number of hospitalizations for surgical procedures in Brazil between 2016 and 2020, according to the type of procedure.

\begin{tabular}{|l|ccccc|}
\hline \multicolumn{1}{|c|}{ Procedure } & $\mathbf{2 0 1 6}$ & $\mathbf{2 0 1 7}$ & $\mathbf{2 0 1 8}$ & $\mathbf{2 0 1 9}$ & $\mathbf{2 0 2 0}$ \\
\hline $\begin{array}{l}\text { Elective } \\
\text { surgeries }\end{array}$ & $1,726,279$ & $1,790,425$ & $1,984,641$ & $2,089,807$ & $1,237,056$ \\
$\begin{array}{l}\text { Urgency } \\
\text { surgeries } \\
\text { Other } \\
\text { procedures }\end{array}$ & $2,644,140$ & $2,716,817$ & $2,774,911$ & $2,844,255$ & $2,714,709$ \\
\hline $\begin{array}{l}\text { Total } \\
\text { surgeries }\end{array}$ & $4,444,988$ & 66,823 & 64,503 & 62,901 & 57,351 \\
\hline
\end{tabular}

The number of surgical hospitalizations in each region between 2016 and 2020 is shown in Table 2. Comparing hospitalizations from 2016 to 2019 and in 2020, there was a $15.81 \%$ reduction in the Southeast, $14.96 \%$ in the Northeast, $14.68 \%$ in the North, $14.37 \%$ in the South, and $11.04 \%$ in the Midwest (average reduction of 14,17\%).

Table 2. Number of hospitalizations for surgical procedures in each of the five Brazilian regions, 20162020.

\begin{tabular}{|l|ccccc|}
\hline \multicolumn{1}{|c|}{ Procedure } & $\mathbf{2 0 1 6}$ & $\mathbf{2 0 1 7}$ & $\mathbf{2 0 1 8}$ & $\mathbf{2 0 1 9}$ & $\mathbf{2 0 2 0}$ \\
\hline North & 325,975 & 342,398 & 360,933 & 366,708 & 297,765 \\
Northeast & $1,160,769$ & $1,189,679$ & $1,286,596$ & $1,321,188$ & $1,054,120$ \\
Midwest & 343,797 & 348,354 & 357,152 & 377,746 & 317,390 \\
Southeast & $1,801,439$ & $1,855,185$ & $1,944,753$ & $2,020,534$ & $1,604,257$ \\
South & 812,427 & 838,449 & 874,621 & 910,787 & 735,584 \\
\hline Total & $4,444,407$ & $4,574,065$ & $4,824,055$ & $4,996,963$ & $4,009,116$ \\
\hline
\end{tabular}

The number of hospitalizations according to the surgical procedures subgroup can be seen in Table 3. Endocrine gland surgery, breast surgery, oral/maxillofacial surgeries, surgery of the upper airways/face/head/neck, and minor surgeries/surgeries of skin/subcutaneous tissue/mucosa were the five subgroups with the highest decrease rates. The lowest decreases were found in reconstructive, osteomuscular, thoracic, oncology and other surgery subgroups. Obstetric surgery was the only subgroup with an increased rate $(0.48 \%)$. 
medRxiv preprint doi: https://doi.org/10.1101/2021.03.17.21253801; this version posted March 20, 2021. The copyright holder for this preprint (which was not certified by peer review) is the author/funder, who has granted medRxiv a license to display the preprint in perpetuity.
It is made available under a CC-BY 4.0 International license.

Table 3. Number of hospitalizations according to the subgroups of surgical procedures between 2016 and 2020 in Brazil.

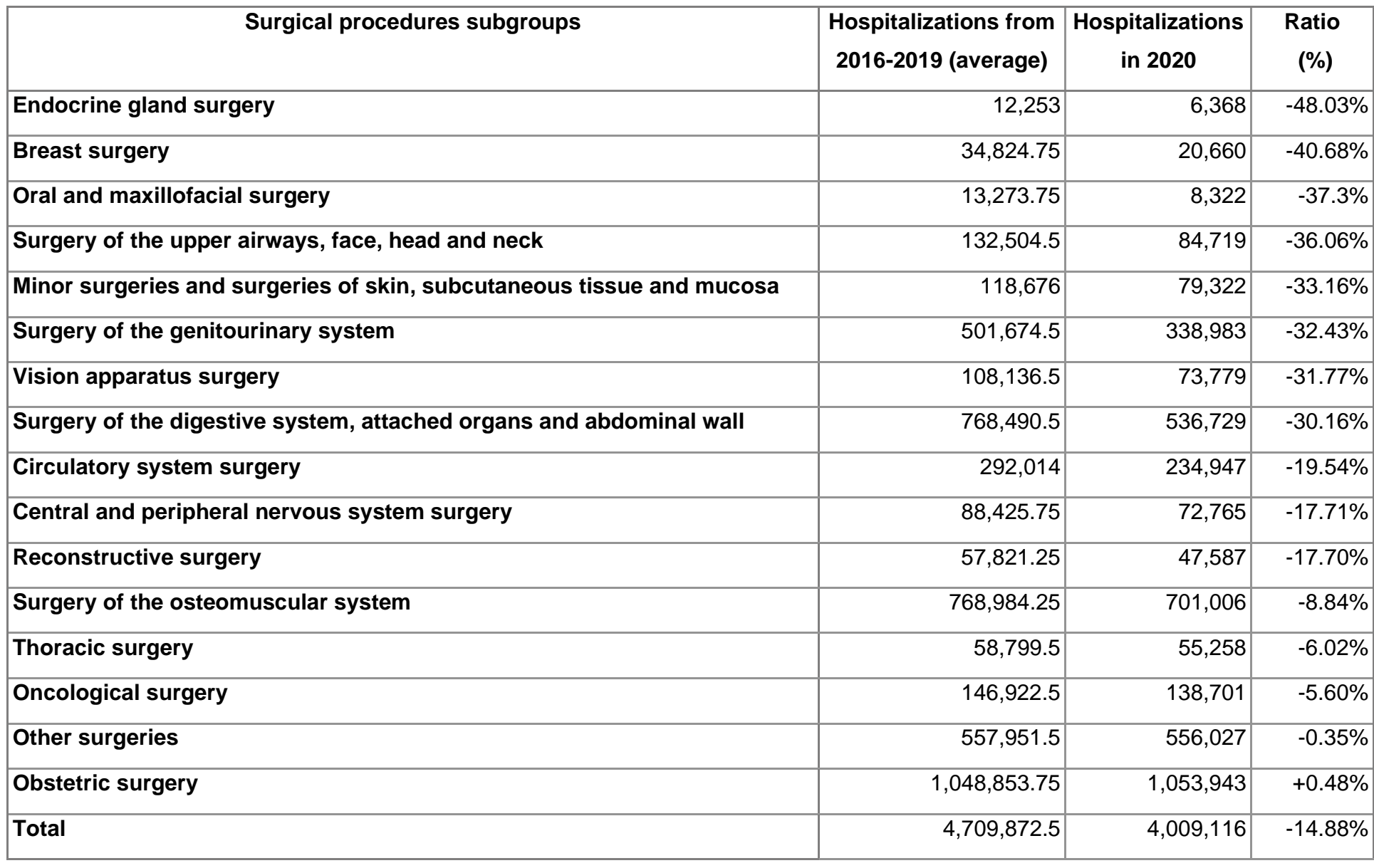

Figure 2 shows the number of hospitalizations per month in 2020. Regarding the 4,009,116 surgical procedures performed, there was a reduction from the beginning to the middle of the year: January (403,829 procedures), February (396,118 procedures [-1.90\%]), March (380,610 procedures [-3.91\%]), April (285.924 procedures [-24.87\%]), May (285.071 procedures [-0.29\%]) and June (276,959 procedures [-2.84\%]). There was an average decrease rate of $6.77 \%$ in this period, with the highest decrease observed from March to April. From July to November, there was an increase in the number of surgeries: July $(299,058$ procedures), August $(310,016$ procedures [+3.66\%]), September $(329,551$ procedures $[+6.30 \%])$, October $(360,078$ procedures $[+9.26 \%])$ and November $(361,027$ procedures [+0.26\%]), with an average increase rate of $5.49 \%$ in this period. In December $(320,875$ procedures), there is a new decrease rate of $11.12 \%$ compared to November. 
medRxiv preprint doi: https://doi.org/10.1101/2021.03.17.21253801; this version posted March 20, 2021. The copyright holder for this preprint (which was not certified by peer review) is the author/funder, who has granted medRxiv a license to display the preprint in

perpetuity.
It is made available under a CC-BY 4.0 International license.

Figure 2. Number hospitalizations for surgical procedures in 2020, per month.

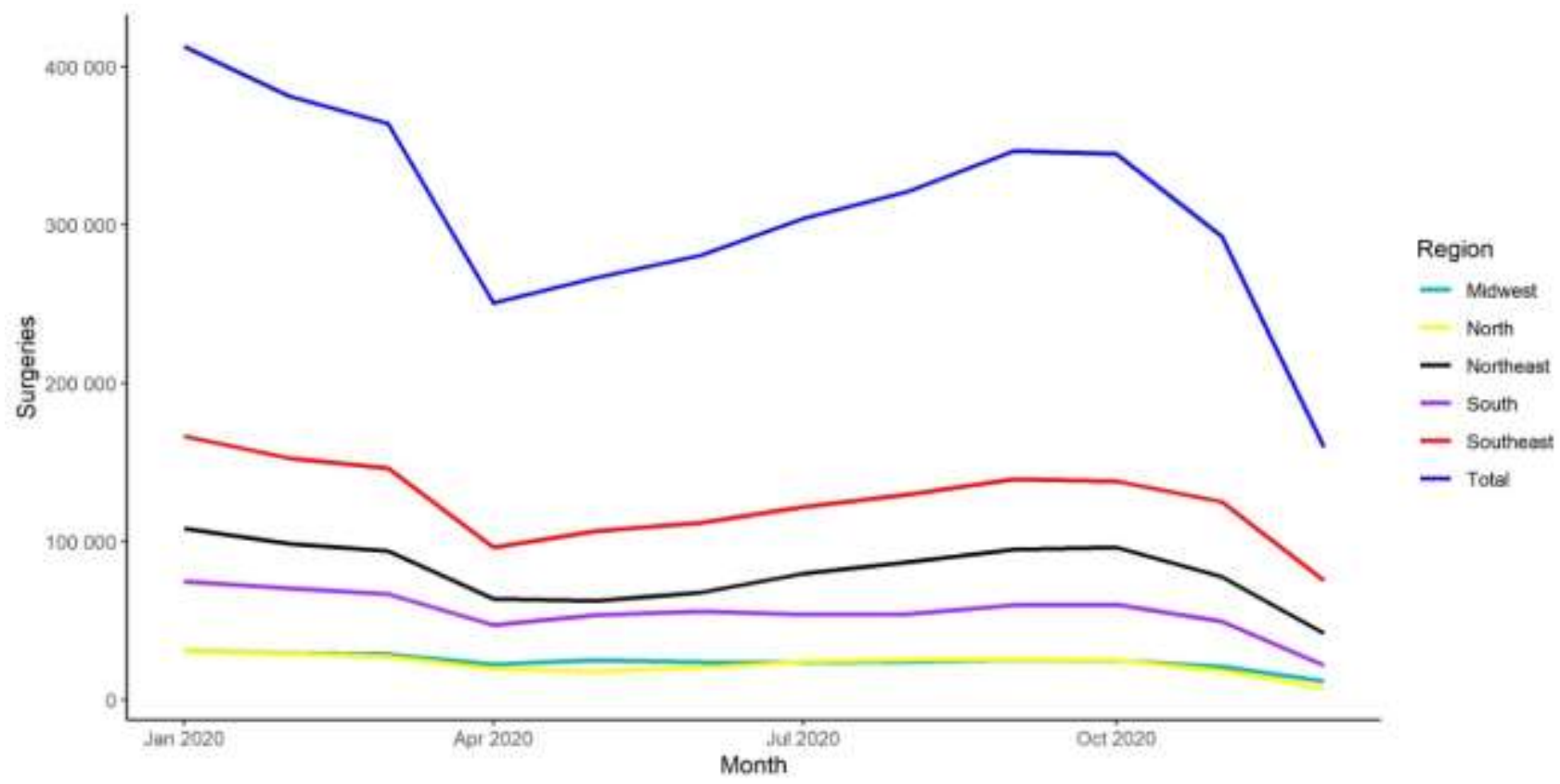

Figure 2 also shows the number of hospitalizations per month in 2020 according to the country's regions. When comparing the hospitalization rates in January and December, there were decreased rates of $36.58 \%$ in North, $22.06 \%$ in South, $19.95 \%$ in Southeast, $19.25 \%$ in Midwest, and $16.49 \%$ Northeast. As well as in the overall analysis, the highest reductions occurred in April and December. In April, there were decreased rates of $27.08 \%$ in Southeast, $24.88 \%$ in Midwest, $24.74 \%$ in South, $23.74 \%$ in Northeast and $21.2 \%$ in North. In December, decrease rates were $26.73 \%$ in North, $12.73 \%$ in Northeast, $10.31 \%$ in South, 9.15\% in Southeast and 1.82\% in Midwest.

According to the National Register of Health Establishments of the Ministry of Health of Brazil, in December 2020, 332,192 health establishments were registered with DATASUS, of which 17,283 in the North, 67,442 in the Northeast, 146,558 in the Southeast, 73,857 in the South and 27,052 in the Midwest. In December 2019, 345,017 were registered with DATASUS, with 17,480 in the North, 68,297 in the Northeast, 162,642 in the Southeast, 70,998 in the South and 25,600 in the Midwest. In December 2018, 331,058 were registered with DATASUS, with 16,958 in the North, 66,343 in the Northeast, 155,229 in the Southeast, 68,105 in the South and 24,423 in the Midwest. In December 2017, 312,783 were registered with DATASUS, with 15,775 in the North, 63,164 in the Northeast, 146,432 in the Southeast, 64,450 in the South and 22,962 in the Midwest. In December 2016, 298,173 were registered with DATASUS, 15,006 in the North, 60,177 in the Northeast, 137,751 in the Southeast, 61,200 in the South and 24,039 in the Midwest [15].

\section{Discussion}

The decision to perform surgeries in the face of the pandemic requires a thorough evaluation to establish priorities and define precisely in which cases benefits overcome risks, and surgery is genuinely needed $[9,16]$. This was a great challenge for surgeons in 2020 , since avoiding unnecessary 
medRxiv preprint doi: https://doi.org/10.1101/2021.03.17.21253801; this version posted March 20, 2021. The copyright holder for this preprint (which was not certified by peer review) is the author/funder, who has granted medRxiv a license to display the preprint in

It is made available under a CC-BY 4.0 International license.

activities in healthcare facilities, thus canceling or postponing all non-urgent procedures, was widely stated as an important measure to prevent overload and enable reorganization of the healthcare systems worldwide [9-11]. The Brazilian public health system adhered to these recommendations, as shown by the decrease of elective surgeries in 2020 (34.82\%) compared to the decline in urgent procedures (1.1\%).

When analyzing monthly surgical procedures in 2020 , there was a remarkably low number of surgeries between April and June, the months following the country's first reported cases, resuming growth from July onwards. Indeed, regulatory measures must be more restrictive at the beginning of an outbreak, when healthcare systems are unprepared to deal with a possible overload, so time is needed until more health resources can be acquired $[9,10]$. There was a new reduction rate in December when compared to the previous months. In the past years (2017-2019), there was a seasonal decrease in hospitalizations for surgical procedures in November and December [17]. Still, the reduction in 2020 could also be attributed to the increase in COVID-19 cases that took part in Brazil in November [18].

Even though Brazil has considerable differences in public administration, heterogeneous cultural and economic conditions across different regions, data shows similar reduction rates in hospitalizations when comparing the rates in 2020 with the previous years, with an average reduction of $18.96 \%$. However, in the 2020 monthly comparison, there was a higher decrease rate in the North in December when compared to the other regions. These reductions might have been the result of the regional healthcare system collapse in December [19].

Surgical care that is not time-critical can be delayed to a later date when the pandemic subsides. However, certain procedures must be performed even during a pandemic, such as cancer treatment and urgent surgeries, as these are considered life-saving procedures [9]. This could explain why oncology and thoracic surgeries suffered minor reductions in the ranking, while endocrine gland surgery was the subgroup with the highest decrease rates $(48.03 \%)$, probably due to the possibility of safe deferral of these procedures [16,20,21].

Regarding plastic surgery, guidelines support the deferral of breast reconstruction and revision procedures [22], which might explain the high decrease rates in breast surgery (40.68\%). Other studies have found that plastic surgery procedures most impacted by the pandemic were superficial skin lesions and subcutaneous mass procedures [23], which corroborates our findings of high decrease rates in minor surgeries and surgeries of skin, subcutaneous tissue and mucosa (33.16\%).

Other subgroups with the highest decrease rates were oral and maxillofacial (37.3\%) and upper airways, head and neck (36.06\%) surgeries. These procedures were of particular concern due to the higher risk of generating aerosols. Guidelines recommend these surgeries should only be performed in life-threatening conditions with great precautions due to the possibility of COVID-19 infection [22,24].

There were also important decrease rates among surgeries of the digestive system and abdominal wall $(30.16 \%)$, which may also reflect recommendations and alternative management of digestive emergency conditions performed during the pandemic. Guidelines support that only lifethreatening gastrointestinal conditions should undergo surgery, and there were recommendations for clinical treatment in conditions such as uncomplicated appendicitis and cholecystitis [17,23], situations in which conservative management appears to be effective and reduce the length of hospital stay [25]. 
medRxiv preprint doi: https://doi.org/10.1101/2021.03.17.21253801; this version posted March 20, 2021. The copyright holder for this preprint (which was not certified by peer review) is the author/funder, who has granted medRxiv a license to display the preprint in It is made available under a CC-BY 4.0 International license.

Cancer surgery was one of the challenges faced in the context of the pandemic. Since both cancer and surgical patients are at high risk of COVID-19 infection and complications of the disease [26-28], there was a concern involving the exposure of these patients to the hospital environment, and most guidelines supported that surgeries should be delayed whenever possible. On the other hand, there were concerns about the risks of postponing oncological procedures and the exposure of patients undergoing conservative cancer treatment. The recommendation was that decisions should be made based on the clinical condition and the pandemic's impact on the local healthcare system [22,27,28]. This study found only a 5.6\% reduction in general oncological surgeries, which suggests that Brazil had a trend in choosing for operation in most cancer cases.

Hospitalization rates for obstetric surgery were slightly higher in 2020 than the average from 2016 to 2019 ( $0.48 \%$ increase). Brazil is one of the countries with the highest cesareans rates, which consisted of $56.3 \%$ of all deliveries in 2019 [29]. Since most guidelines support that maternal COVID19 infection should not influence the type of delivery [30], it should be safe to assume that the pandemic did not significantly impact this group of procedures.

COVID-19 has had a devastating impact on patients, the economy and healthcare systems. There is hope that cases will begin to decline soon and, as the COVID-19 vaccine is distributed, hospitals must develop protocols to resume elective surgeries safely. This will be the next challenge for the surgical community. Moving forward requires not only creativity but also structural changes to patient workflows [31-33].

Regarding the long-term effects on surgical practice, this pandemic should raise awareness regarding protective measures to both surgical staff and patients, and the protocols' changes made to reduce the risk of contamination during surgical procedures should be added to operating theaters routines.

This study has limitations: the data refer only to the Brazilian public health system because data from the private health system are not available, which might lead to an overestimation of the decrease rates. As secondary data, the veracity of the information provided depends on proper registration.

Although regression analyses that could help explain the differences in the number of surgeries between subgroups and regions were not performed, some justifications for the temporal trends of reduction in surgical procedures are speculated, such as the correlation with decrees and laws of state and municipal governments that imposed the postponement of elective surgeries.

\section{Conclusion}

COVID-19 pandemic has promoted changes in the surgical practice in Brazil. The need for minimizing the overload in healthcare facilities has demanded reductions in healthcare activities and avoidance of non-urgent procedures, as seen by the notable decline in elective surgeries. Lower numbers of procedures were seen in April, July and December of 2020, periods of an increasing number of cases in the country. 
medRxiv preprint doi: https://doi.org/10.1101/2021.03.17.21253801; this version posted March 20, 2021. The copyright holder for this preprint (which was not certified by peer review) is the author/funder, who has granted medRxiv a license to display the preprint in perpetuity.
It is made available under a CC-BY 4.0 International license.

Continuous refinements of safety recommendations are encouraged because of evolving circumstances. The new protocols developed during the pandemic should be implemented and improved for patients and staff safety in the long term.

Declarations of interest: None.

Funding: This research did not receive any specific grant from funding agencies in the public, commercial, or not-for-profit sectors.

CRediT author statement: Bárbara Okabaiasse Luizeti: Conceptualization; Methodology; Investigation; Writing - Original Draft; Project administration. Victor Augusto Santos Perli: Methodology; Investigation; Resources; Writing - Original Draft. Gabriel Gonçalves da Costa: Software; Formal analysis; Data Curation; Writing - Review \& Editing. Igor da Conceição Eckert: Validation; Writing Review \& Editing. Aluisio Marino Roma: Validation; Visualization. Karina Miura da Costa: Writing Original Draft; Supervision.

\section{References}

1. N. Zhu, D. Zhang, W. Wang, X. Li, B. Yang, J. Song, X. Zhao, B. Huang, W. Shi, R. Lu, P. Niu, F. Zhan, X. Ma, D. Wang, W. Xu, G. Wu, G. F. Gao, D. Phil, W. Tan, A Novel Coronavirus from Patients with Pneumonia in China, 2019, N. Engl. J. Med. 382 (2020) 727733. https://doi.org/10.1056/NEJMoa2001017.

2. World Health Organization. Novel Coronavirus (2019-nCoV) SITUATION REPORT - 1. https://www.who.int/docs/default-source/coronaviruse/situation-reports/20200121-sitrep-12019-ncov.pdf?sfvrsn=20a99c10_4, 2020 (accessed 13 February 2021).

3. A. Wilder-Smith, C. J. Chiew CJ, V. J. Lee, Can we contain the COVID-19 outbreak with the same measures as for SARS?, The Lancet Infect. Dis. 20 (2020) e102-e107. https://doi.org/10.1016/S1473-3099(20)30129-8.

4. World Health Organization, Coronavirus disease 2019 (COVID-19) Situation Report - 51. https://www.who.int/docs/default-source/coronaviruse/situation-reports/20200311-sitrep-51covid-19.pdf?sfvrsn=1ba62e57_10, 2020 (accessed 13 February 2021).

5. Y. Lee, A. Kirubarajan, N. Patro, M. S. Soon, A. G. Doumouras, Impact of hospital lockdown secondary to COVID-19 and past pandemics on surgical practice: A living rapid systematic review, Am. J. Surg. (2020), https://doi.org/10.1016/j.amjsurg.2020.11.019.

6. E. J. Emanuel, G. Persad, R. Upshur, B. Thome, M. Parker, A. Glickman, C. Zhang, C. Boyle, M. Smith, J. P. Phillips, Fair Allocation of Scarce Medical Resources in the Time of Covid-19, N. Engl. J. Med. 382 (2020); 2049-2055. https://doi.org/10.1056/NEJMsb2005114.

7. H. Kurihara, P. Bisagni, R. Faccincani, M. Zago, COVID-19 outbreak in Northern Italy: Viewpoint of the Milan area surgical community, J. Trauma Acute Care Surg. 88 (2020) 719724. https://doi.org/doi:\%2010.1097/TA.0000000000002695. 
medRxiv preprint doi: https://doi.org/10.1101/2021.03.17.21253801; this version posted March 20, 2021. The copyright holder for this preprint (which was not certified by peer review) is the author/funder, who has granted medRxiv a license to display the preprint in perpetuity.
It is made available under a CC-BY 4.0 International license.

8. A. Al-Jabir, A. Kerwan, M. Nicola, Z. Alsafi, M. Khan, C. Sohrabi, N. O'Neill, C. losifidis, M. Griffin, G. Mathew, R. Agha, Impact of the Coronavirus (COVID-19) pandemic on surgical practice - Part 1, Int. J. Surg. 79 (2020) 168-179. https://doi.org/10.1016/j.ijsu.2020.05.022.

9. K. Søreide, J. Hallet, J. B. Matthews, A. A. Schnitzbauer, P. D. Line, P. B. S. Lai, J. Otero, D. Callegaro, S. G. Warner, N. N. Baxter, C. S. C. Teh, J. Ng-Kamstra, J. G. Meara, L. Hagander, L. Lorenzon, Immediate and long-term impact of the COVID-19 pandemic on delivery of surgical services, BJS. 107 (2020) 1250-1261. https://doi.org/10.1002/bjs.11670.

10. COVIDSurg Collaborative, Global guidance for surgical care during the COVID-19 pandemic. BJS. 107 (2020) 1097-1103. https://doi.org/10.1002/bjs.11646.

11. G. Lacobucci, Covid-19: all non-urgent elective surgery is suspended for at least three months in England, BMJ. 368 (2020) m1106. https://doi.org/10.1136/bmj.m1106.

12. Z. M. Jessop, T. D. Dobbs, S. R. Ali, E. Combellack, R. Clancy, N. Ibrahim, T. H. Jovic, A. J. Kaur, A. Nijran, T. B. O'Neill, I. S. Whitaker, Personal protective equipment for surgeons during COVID-19 pandemic: systematic review of availability, usage and rationing, BJS. 107 (2020) 1262-1280. https://doi.org/10.1002/bjs.11750.

13. M. R. Kibbe, Surgery and COVID-19, JAMA. 324 (2020) 1151-1152. https://doi.org/10.1001/jama.2020.15191.

14. E. H. Livingston, Surgery in a Time of Uncertainty: A Need for Universal Respiratory Precautions in the Operating Room, JAMA. 323 (2020) 2254-2255. https://doi.org/10.1001/jama.2020.7903.

15. Ministry of Health of Brazil, National Register of Health Establishments. https://cnes.datasus.gov.br, 2021 (accessed 11 March 11 2021).

16. L. Moletta, E. S. Pierobon, G. Capovilla, M. Constantini, R. Salvador, S. Merigliano, M. Valsamoni, International guidelines and recommendations for surgery during Covid-19 pandemic: A Systematic Review, Int. J. Surg. 79 (2020) 180-188. https://doi.org/10.1016/j.ijsu.2020.05.061.

17. Ministry of Health, Brazil, Hospital Information System of SUS (SIH), DATASUS, 2021. http://tabnet.datasus.gov.br/cgi/deftohtm.exe?sih/cnv/qiuf.def.

18. Johns Hopkins University \& Medicine, Coronavirus Resource Center. https://coronavirus.jhu.edu/map.html, 2021 (accessed 5 March 2021).

19. Ministry of Health of Brazil, COVID-19 in Brazil. https://susanalitico.saude.gov.br/extensions/covid-19_html/covid-19_html.html, 2021 (accessed 5 March 2021).

20. C.P. Lombardi, A. D'Amore, G. Grani, V. Ramundo, M. Boscherini, L. Gordini, F. Marzi, S. Tedesco, R. Bocale, Endocrine surgery during COVID-19 pandemic: do we need an update of indications in Italy? Endocrine. 68 (2020) 485-488. https://doi.org/10.1007/s12020-020-023577.

21. R. Palladino, I. Migliatico, R. Sgariglia, M. Nacchio, A. Iaccarino, U. Malapelle, E. Vigliar, D. Salvatore, G. Troncone, C. Bellevicine, Thyroid fine-needle aspiration trends before, during, 
medRxiv preprint doi: https://doi.org/10.1101/2021.03.17.21253801; this version posted March 20, 2021. The copyright holder for this preprint (which was not certified by peer review) is the author/funder, who has granted medRxiv a license to display the preprint in It is made available under a CC-BY 4.0 International license .

and after the lockdown: what we have learned so far from the COVID-19 pandemic, Endocrine. 71 (2021) 20-25. https://doi.org/10.1007/s12020-020-02559-z.

22. A. Al-Jabir, A. Kerwan, M. Nicola, Z. Alsafi, M. Khan, C. Sohrabi, N. O'Neill, C. Iosifidis, M. Griffin, G. Mathew, R. Agha, Impact of the Coronavirus (COVID-19) pandemic on surgical practice - Part 2 (surgical priorisation), Int. J. Surg. 79 (2020) 233-248. https://doi.org/10.1016/j.ijsu.2020.05.002.

23. M. Kara, B. Akduman, Y. M. Isik, K. Gürsoy, U. Koçer, Impact of COVID-19 outbreak on plastic surgery: Taken precautions, distribution of surgical procedures and changes in admissions to outpatient clinic, J. Plast. Reconstr. Aesthet. Surg. (2020), https://doi.org/10.1016/j.bjps.2020.10.073.

24. M. Zimmermann, E. Nkenke, Approaches to the management of patients in oral and maxillofacial surgery during COVID-19 pandemic, J. Craniomaxillofac. Surg. 48 (2020) 521526. https://doi.org/10.1016/j.jcms.2020.03.011.

25. H. Javanmard-Emanghissi, H. Boyd-Carson, M. Hollyman, B. Doleman, A. Adiamah, J. N. Lund, R. Clifford, L. Dickerson, S. Richards, L. Pearce, J. Cornish, S. Hare, S. Lockwood, S. J. Moug, G. M. Tierney, The management of adult appendicitis during the COVID-19 pandemic: an interim analysis of a UK cohort study, Tech. Coloproctol. (2020), https://doi.org/10.1007/s10151-020-02297-4.

26. COVIDSurg Collaborative, Mortality and pulmonary complications in patients undergoing surgery with perioperative SARS-CoV-2 infection: an international cohort study, The Lancet. 396 (2020) 27-38. https://doi.org/10.1016/S0140-6736(20)31182-X.

27. American College of Surgeons (ACS). ACS Guidelines for Triage and Management of Elective Cancer Surgery Cases During the Acute and Recovery Phases of Coronavirus Disease 2019 (COVID-19)

Pandemic.

https://www.facs.org//media/files/covid19/acs_triage_and_management_elective_cancer_surgery_during_acute_a nd_recovery_phases.ashx, 2020 (accessed 18 February 2021).

28. F. Huda, P. Kumar, S. K. Singh, S. Agrawal, S. Basu, Covid-19 and surgery: Challenging issues in the face of new normal - A narrative review, Ann. Med. Surg. 60 (2020) 162-167. https://doi.org/10.1016/j.amsu.2020.10.039.

29. Ministry of Health of Brazil, Information System of Born Alive (SINASC), DATASUS, 2021. http://tabnet.datasus.gov.br/cgi/tabcgi.exe?sinasc/cnv/nvuf.def.

30. P. Pavlidis, K. Eddy, L. Phung, E. Farrington, M. Connolly, R. Lopes, A. N. Wilson, C. S. E. Homer, J. P. Vogel, Clinical guidelines for caring for women with COVID-19 during pregnancy, childbirth and the immediate postpartum period Women and Birth. (2020), https://doi.org/10.1016/j.wombi.2020.10.015.

31. K. Kaye, F. Paprottka, G. Casabona, J. Montes, R. Fakin, L. Moke, T. Stasch, D. Ritcher, J. Benito-Ruiz, Elective, Non-urgent Procedures and Aesthetic Surgery in the Wake of SARSCOVID-19: Considerations Regarding Safety, Feasibility and Impact on Clinical Management, Aesthetic Plast. Surg. 44 (2020) 1014-1042. https://doi.org/10.1007/s00266-020-01752-9. 
medRxiv preprint doi: https://doi.org/10.1101/2021.03.17.21253801; this version posted March 20, 2021. The copyright holder for this preprint (which was not certified by peer review) is the author/funder, who has granted medRxiv a license to display the preprint in It is made available under a CC-BY 4.0 International license.

32. J. C. Bonano, J. I. Huddleston III, Perioperative Medical and Surgical Coronavirus Disease 2019 Issues: Keeping Surgeons, Operating Room Teams, and Patients Safe, J. Arthroplasty. (2021), https://doi.org/10.1016/j.arth.2021.01.047.

33. J. W. Meredith, K. P. High, J. A. Freischlag, Preserving Elective Surgeries in the COVID-19 Pandemic and the Future, JAMA. 324 (2020) 1725-1726. https://doi.org/10.1001/jama.2020.19594. 